\title{
On Liability of Joint Dangerous Act
}

\author{
Di Wu ${ }^{1, a}$ \\ ${ }^{1}$ Oxbridge College, Kunming University of Science Technology, Kunming, Yunnan Province, China \\ a916952589@qq.com
}

Keywords: Joint Dangerous Act, Uncertain Tortfeasor, Liability, Exemption.

\begin{abstract}
Joint dangerous act is a relative special pattern of tortious act. Different doctrines on liability fixation for specific behaviors of joint dangerous act can lead to the differences in behavioral nature. The uncertain tortfeasor differentiate joint dangerous act from other forms of tortious behaviors. Clearly and thoroughly analyses on the constitute elements of joint dangerous act, and liability bearing in cases with uncertain tortfeasors, are key to joint dangerous act study.
\end{abstract}

\section{Introduction}

Joint dangerous act means tortious act without certain tortfeasor. As a kind of joint tort, joint dangerous act has the general characteristics of joint tort: two or above actors. This feature makes joint dangerous behaviors special. Actors should bear liability of the joint tort together, but if the tortfeasors are unknown, the liability bearing will be tricky. Scholars are seeking for a solution on liability allocation which all actors can accept.

\section{Constitute Elements of Joint Dangerous Act}

The aim of analyzing constitute elements of joint dangerous act is to determine which kinds of joint behaviors can be classified as tort, and whether joint dangerous actors should bear corresponding civil liability or not. On the constitute elements of general tort, the author agrees with the Four Elements Theory advocated by Li-ming Wang, Li-xin Yang and other scholars. For the special tort behaviors, the author follows the Three Elements Theory. Then the constitute elements of joint dangerous act are discussed from four aspects.

The first element is the common injury act[1]. Joint dangerous act is done by two or above people. If only one person commit the tort, the behavior cannot be classified as joint tort, and the reliability bearing is identified. It is the prerequisite of joint tort that more than one actor commit the tort. Tortious behaviors include direct injuries and quasi tort. Quasi tort means that, though the offenders do not make injuries directly, they should take responsible of the injuries; related examples include hanging objects fall off and domesticated animal tort.

The second element is the damage fact. There is an unwritten principle in the determination of tort liability: "no damage, no liability". It shows that the damage result decides whether the actor should bear liability or not. As a branch of the Civil Law, Tort Liability Law follows the basic principles of Civil Law, which clearly prohibit victims to seek for unreasonable interests through the damage of their own rights. The Tort Liability Law makes more clearly regulations, and points out that the main function of this law is to remedy damage. If there is no damage, there is no need to use Tort Liability Law.

The third element is the causal relationship between actors' behaviors and victims' damage. The causation theory has been discussed for a long time, and there's still a variety of disputes. The author agrees with the Theory of Common Causality, which believes that the actors should bear reliability for their common and conditional behaviors which harm to others. [2] Theory of Common Causality holds that, the causal relationship can set up only under two conditions. The damage of victims will not happen without actors' behaviors; the tort of actors will probably cause victims' damage. The subjective behavior and objective result build up a causal relationship between the injury act and the damage fact. 
The fourth element is the subjective faults of joint dangerous actors. The subjective faults include joint intention, joint negligence, both intention and negligence. If the actor has subjective faults on the injury, the actor should be responsible for the fault, and bear corresponding liability for compensation. However, when determining whether the actor has subjective fault, different kinds of situation should be treated differently. It has been mentioned in the above passage that behavioral natures of joint dangerous act are different, including tort and quasi tort. Before determining whether the subjective faults of actors should be considered as one element in joint dangerous act, the nature of the joint dangerous act must be determined first. Joint dangerous behaviors can be divided into general tortious behaviors and special tortious behaviors[3]. If the act belongs to general tort such as property damage and infringement personal rights, it should satisfy all the four elements. If the act belongs to special tort such as environment pollution and damage caused by domesticate animal, it needs to satisfy only three elements, namely injury act, damage fact and casual relationship. The subjective fault is not an essential condition.

\section{Uncertain Tortfeasor in Joint Dangerous Act}

Uncertain tortfeasor is the feature which distinguish joint dangerous act with other kinds of tort; it is also the difficulty in determining and bearing reliability of joint dangerous act. The Tort Liability Law makes clear provision on joint dangerous act in tenth article. The core of this provision is "the specific tortfeasor cannot be determined". If the specific tortfeasor cannot be determined, victims' demands on compensation will be difficult to be satisfied. The following passage further analyzes the uncertain tortfeasor in joint dangerous act.

The so-called common joint dangerous act refers tort committed by several people and cause damage to the victim. But it is impossible to determine the specific liability of each person. For example, three people $\mathrm{A}, \mathrm{B}$ and $\mathrm{C}$ met on the roof, and then threw bricks to the ground together. $\mathrm{D}$ passed by and was hit by a brick on his head. D spent ten thousand yuan for medical expenses. In this case $\mathrm{A}, \mathrm{B}$ and $\mathrm{C}$ committed the tort together, and caused damage to $\mathrm{D}$. But it was difficult to determine which one was responsible for the damage. This feature distinguishes joint dangerous act with and other forms of tort, and it is necessary for Tort Liability Law to make specific provisions on it.

Although these behaviors are expressed as "joint dangerous act" [4], they may not highly dangerous in real life. Different from highly dangerous activities like mishandling high temperature, high pressure, inflammable or explosive materials, the term of "dangerous" in joint dangerous act is used to emphasize the objective possibility of damage. All behaviors which may injure the legitimate rights and interests of others can be classified as joint dangerous act. So the scope of joint dangerous act is very wide.

The Tort Liability Law stipulates in the Tenth article that, if two or more persons commit an act that jeopardizes the safety of another or the safety of the property of another, and the specific tortfeasor can be determined, the tortfeasor shall bear the liability. These kinds of cases belong to separate tort, or joint tort in narrow sense, rather than joint dangerous act. If the specific tortfeasor cannot be determined, the case should be regarded as joint dangerous act. Thus, the uncertain tortfeasor is the feature of joint dangerous act. [5] Uncertain tortfeasor is different from uncertain liability allocation. In the cases of uncertain liability allocation, tortfeasors can be determined, and the bearing liability of compensation is determined, too. The extent of actors' tortious behaviors lead to different compensation share. So these cases still belong to joint tort in narrow sense. If the tortfeasor is not clear, it will be difficult to tell whether joint actors should take responsible for the damage. It is a problem in joint dangerous act system which should be solved.

\section{Liability of Joint Dangerous Act}

The uncertain tortfeasor is the feature of joint dangerous act, which makes liability allocation difficult to be achieved. 
Joint and several liabilities taken by joint dangerous actors. The Tort Liability Law stipulates in the tenth article that, if two or more persons commit an act that jeopardizes the safety of another or the safety of the property of another, and the specific tortfeasor cannot be determined, the actors shall bear joint and several liabilities. Judicial Interpretations on Compensation for Person Damage stipules in the fourth article that, joint dangerous actors should take joint and several liabilities in accordance with the provision of 130th article in the General Principles of the Civil Law.

Joint and several liabilities mean that, victims can request compensation for all losses to one actor several actors. And if any one actor or several actors have paid all losses, the other joint actors do not need to compensate for the loss of the victim. [6] The jointly liability shows that the main function of Tort Liability Law is damage remedy. After that, victims' rights can be restored through legal relief, but they are not allowed to seek for more rights and interests.

Under the condition of uncertain tortfeasor, policy about joint and several liabilities guarantee the legitimate rights and interests of victims. Without these provisions, victims may not get compensation, or cannot find proper method to protect their rights.

Internal allocation of joint dangerous actors' liability. After taken joint and several liabilities, how to allocate internal liabilities among actors? There's no clear legal provision on that issue. But in judicial practices, the regulation is "equally share". The author agrees with this rule.

Joint dangerous act is a type of joint tort. Uncertain tortfeasor distinguishes joint dangerous act with other kinds of tort. In cases of joint dangerous act, the behaviors of actors are similar. Their probabilities of causing damage are similar, too. Thus, the specific tortfeasor cannot be determined, since the tortfeasor can be any one in the group.

Under that situation, the proportion of reliability cannot be determined. According to the fair principle of the Civil Law, if the extent of each person's liability is impossible to determine, actors shall each be liable for damages equally.

Exemptions for joint dangerous actors. The Tort Liability Law stipulates that in joint dangerous act which causes victims' damage, if the specific tortfeasor cannot be determined, the actors shall bear joint and several liabilities. The provision protects the rights and interests of victims, but it is unfair to joint dangerous actors who do not commit tortious act. Therefore, corresponding judicial interpretation on exemptions for joint dangerous actors was published. If the actor can show evidence which meets the requirement of exemption, the actor could be exempted from bearing liability. There are two points of view on the exemption evidence, namely the "Positive Theory" and "Negative Theory".

The "Positive Theory" seems to be the general theory in academic field. The joint dangerous act has different nature from general tort, and it may belong to special tort. In other words, joint dangerous act cannot take place without at least three elements, namely injury act, damage fact and causal relationship. If there's one element missing, the tort cannot take place. The actor does not need to bear liability under that circumstance. Therefore, "Positive Theory" holds that[7], in cases of joint dangerous act, if one actor has evidence to prove that he or she did not commit tortious act, or there was no causal relationship between the damage result and his or her injury act, the actor can be exempted. This view requires the actor to show there's no relationship between injury act and damage fact. The actor does not need to identify the specific tortfeasor, and the burden of proof is relatively light.

"Negative theory" makes more strict requirements on actors' evidence.[8] It holds that, though one actor has evidence to prove his or her innocence, the actor cannot be exempted unless he or she can identify the specific tortfeasor.

The author agrees with the "Positive Theory". The constitutive elements of tort are very clear. If there's one element missing, the tort cannot take place. The actor does not need to bear liability under that circumstance. "Negative theory" makes too strict requirements to actors. If one actor has evidence to prove that he or she did not commit tortious act, or there was no causal relationship between the damage result and his or her injury act, but he or she do not know the specific tortfeasor, the actor still needs to bear joint and several liabilities. It is unfair to these actors. The legitimate rights 
and interests of victims and actors should be equally protected. Therefore, the author believes that "Positive Theory" is more consistent with the pursuit of society ruled by law.

\section{References}

[1] J.Q. Ye, Type elements and legal effects of joint infringement, J. China Legal Science. 1(2010).

[2] X. Cheng, On the meaning of "joint implementation" in article eighth of Tort Liability Law, J. Tsinghua Law Review. 2 (2010).

[3] X.H. Li, On joint dangerous act, J. Journal of East China University of Political Science and Law. $2(2011)$.

[4][5] L.M. Wang, The uncertain infringer in joint dangerous act, J. Political Science and Law. 4 (2010).

[6] Z.J. Wang, Tort Law, Peking University Press, Beijing, 2009.

[7] H.H. Huo, On exemption from common dangerous act of causal relationship missing -- the tenth article of Tort Liability Law centered analysis, J. Peking University Law Journal. 1 (2015).

[8] X.B Zhang, Tort Liability Law of People's Republic of China, M. China Renmin University Press, Beijing, 2013 